\title{
The Transcontextualization of Sustainable Development in a Mining Exploration Milieu: A Transect on the Alangan Mangyans
}

\author{
Dindo Palce Café ${ }^{1}$ \\ ${ }^{1}$ De La Salle University, Taft, Malate, Manila, Philippines \\ Correspondence: Dindo Palce Café, De La Salle University, Taft, Malate, Manila, Philippines. E-mail: \\ dindo.cafe@dlsu.edu.ph
}

Received: February 23, 2012 Accepted: April 11, 2012 Online Published: May 1, 2012

doi:10.5539/jsd.v5n5p150

URL: http://dx.doi.org/10.5539/jsd.v5n5p150

\begin{abstract}
This study contends that although an array of factors may impinge on the evolution of the development perspective of indigenous peoples, the discourse of globalization orchestrated through mining exploration is a crucial force in reconstructing the concept of sustainable development. In broad stroke, the inquiry centers on the amphimixis of etic and emic perspectives of sustainable development, ancestral domain, and eco-spirituality as manifested in the mining exploration in Victoria, Mindoro Oriental, Philippines. Based on the ethnographic accounts gathered through in-depth interviews, focus group discussions, and observation, the study concludes that Alangan Mangyans have holistic concept of sustainable development. The interconnection between the concept of sustainable development, ancestral domain and eco-spirituality asserts that the development perspective of Alangan Mangyans has been a product of long experience and not merely a reflection of a primitive way of life. The transcontextualization of the aforesaid concepts has been orchestrated by the discourse of globalization manifested in the realm of mining exploration.
\end{abstract}

Keywords: transcontextualization, sustainable development, ancestral domain, eco-spirituality, etic, emic

\section{Transcontextualization of Sustainable Development: A Panoptic Gaze on the Alangan Mangyans}

History has proven that different societies are continuously transformed through time. The factors that propel transformation can be internal or external. Internal factors can be associated to the self-initiative of people in a society to effect change on their culture. On the other hand, external factors refer to the influences coming from the outside of the society.

In third world countries like the Philippines, external factors on cultural and social change are common. The case in point is the immense and diverse effects of globalization on our society. The neo-liberal principle of economy that propagates export-led growth has resulted in tremendous exploitation of natural resources. It has affected the Philippine society in different ways. One of the glaring effects is the evolution of the concept of sustainable development, ancestral domain, and eco-sprituality.

Theoretically, the characterization of change in the concept of sustainable development, ancestral domain, and eco-spirituality is an elaboration of the interplay between humans and social structure. Society hones humans and their perspective but every individual can modify or revolutionize it. Pierre Bourdieu (in Ritzer, 1996) asserts that all actions involve field and habitus that are inextricably interwoven in ongoing human activity or practice. This theoretical postulate is the key theme of this paper. In broad stroke, the inquiry centers on the confluence of etic and emic concepts of sustainable development, ancestral domain, and eco-spirituality among Alangan Mangyans. Specifically, this paper aims to (1) Identify indigenous concepts of sustainable development, ancestral domain, and eco-spirituality; (2) Describe the vestigial concepts of sustainable development, ancestral domain, and eco-spirituality; (3) Identify the factors that facilitate the transcontextualization of the concept of sustainable development, ancestral domain, and eco-spirituality; and (4) Formulate recommendations on how to improve the stewardship of Alangan Mangyans on the preservation of their concept of sustainable development, ancestral domain, and eco-spirituality.

\section{The Etic and Emic Nexus: A Theoretical-Conceptual Framework}

The theory of field and habitus by Pierre Bourdieu is used as framework in contextualizaing the concepts of sustainable development, ancestral domain, and eco-spirituality among Alangan Mangyans. This theory highlights the linkage between the capacity of an individual to be autonomous in determining his behavior and 
thoughts and the power of the society or social structure to impose general behavioral patterns. This is corollary to the main thesis of this study to demonstrate that a human being thinks objectively but acts subjectively. Succinctly, the paper claims that etic and emic cultures are not dichotomous and binary opposites but rather exist in a dialectical coordinates.

Pierre Bourdieu subscribes the dialectical nature between objective and subjective culture. He states that:

The objective structures...form the basis for... representations and constitute the structural constraints that bear upon interactions; but, on the other hand, these representations must also be taken into consideration particularly if one wants to account for the daily struggles, individual and collective, which purports to transform or preserve these structures (Ritzer, 1996).

The theoretical formulation of Bourdieu illustrates the reciprocal relationship between man or agency and society or structure. Man shapes the society and on the other hand society shapes man.

The conceptual framework (see Figure 1) presents as a heuristic device to sketch the process of convergence of the etic and emic concepts of sustainable development, ancestral domain, and eco-spirituality. The etic aspect refers to the development perspective external to the Alangan Mangyans. On the other hand, emic aspect is the peculiar and unique perspectival and cultural orientation of the Alangan Mangyans. The mainstreaming process of etic concept of sustainable development, ancestral domain, and eco-spirituality facilitates collective perspective among Alangan Mangyans. Constraining factors may deter the mainstreaming process and will result to the retention of emic indigenous perspective. Reflexive or fusion of etic and emic development perspective happens with the presence of facilitating factors and the absence of resistance from the Alangan Mangyans. In the long run, reflexive development perspective becomes the object for mainstreaming process.

\section{Ethnography as a Methodological Approach}

This paper uses qualitative methods in gathering data on the concepts of sustainable development, ancestral domain, and eco-spirituality. Series of fieldworks were done to come up with an exhaustive and comprehensive understanding of the development perspective among Alangan Mangyans. Ethnographic accounts were gathered by utilizing mixed methods. Ethnographic texts are instrumental in the distillation of the concepts of sustainable development, ancestral domain, and eco-spirituality among Alangan Mangyans.

First, in-depth interviews with elders and tribal leaders were done in order to tease out ethnographic accounts regarding the concept of sustainable development among Alangan Mangyans. The primary aim of the interview is to look into the unique concept of sustainable development in relation to ancestral domain and eco-spirituality among Alangan Mangyans. There were five key informants, two tribal leaders and three elders. These key informants were selected on the premise that they have broad knowledge and understanding of the development discourse of Alangan Mangyans.

Second, focus group discussions (FGD) were utilized in gathering data regarding the vestigial concepts of sustainable development, ancestral domain, and eco-spirituality. Also, FGD was used to identify the facilitating factors of the transformation of development perspective among Alangan Mangyans. Moreover, FGD was instrumental in eliciting recommendations on how to improve the stewardship of Alangan Mangyans on the preservation of their development perspective. There were two FGDs conducted among Alangan Manyans elders and tribal leaders. The first and second group was composed of five and four members respectively. The composition of each group was varied in terms of age, gender, political status. This is taken into consideration in order to ascertain extensive information from the group.

Third, observation was done particularly during the early phase of the fieldwork. Details on the performance of rituals, daily activities, and artifacts were gathered through observation. This method was instrumental in arriving at a deeper understanding of the cultural heritage of Alangan Mangyans. The actual exposure to their rituals and daily activities amplifies the meanings and interpretations of the data gathered through in-depth interviews and focus group discussions. 


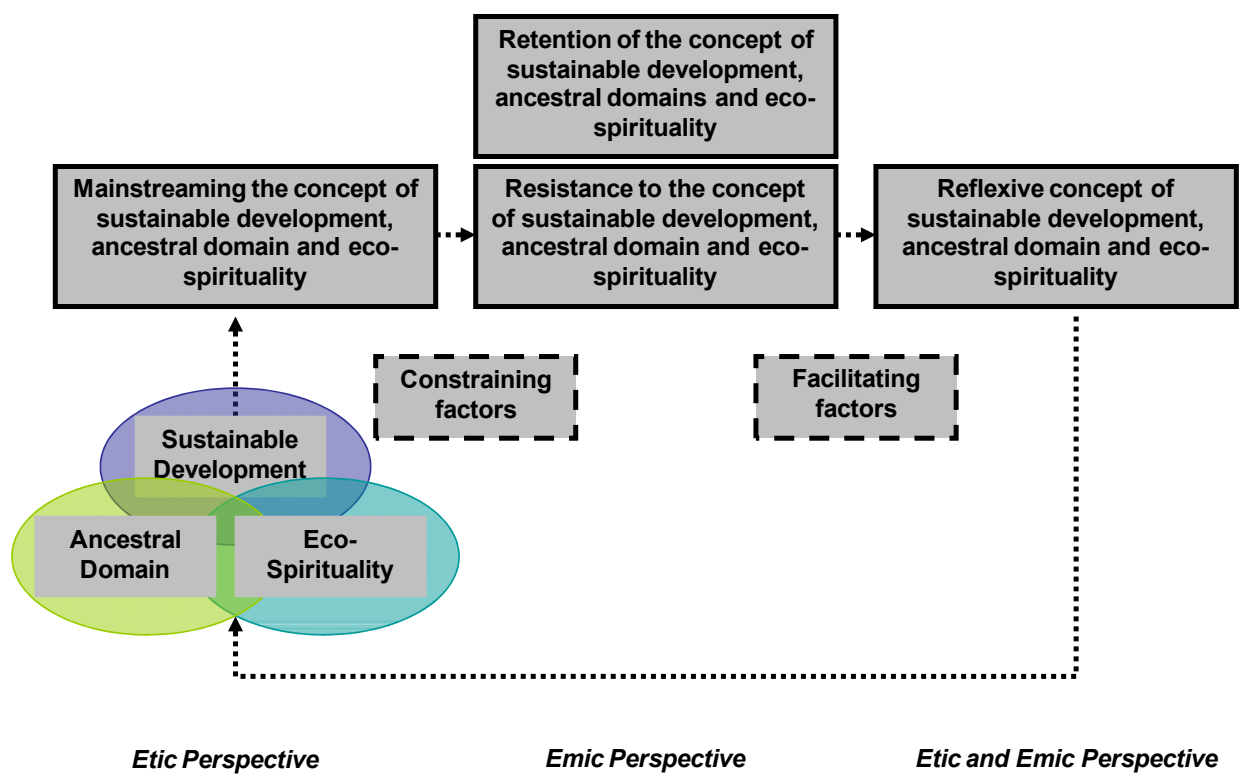

Figure 1. Conceptual framework

\section{Alangan Mangyans Under Siege of Mining Exploration}

Mangyan is a term used by the lowlanders ("damuong") that refers to the indigenous peoples that settle in interiors of Mindoro. Alangan Mangyan is one among the four Mangyan groups that inhabit Barangay Villa Cerveza in the municipality of Victoria, Mindoro Oriental. The Alangans, Tadyawans, Bangons and newly recognized tribe at least among themselves, the Ruwang live in the mountainous area of the northern part of Oriental Mindoro, particularly on the foothills and interior of part of the Municipalities of Victoria, Mindoro Oriental and Sablayan Mindoro Occidental. The name Alangan has originated from Alangan River and Alangan Valley whom the inhabitants associated themselves with their place of abode.

The influx of migrants to Mindoro was propelled by the declaration of the government of all public lands in the province as disposable through homestead or agricultural use. In search for source of livelihoods, the Visayans, Bicolanos, and Tagalogs migrated to the area. Agriculture and logging are strong pull factors of migration and causes displacement and resettlement to remote areas among Mangyans. The government issuance of licenses to commercial logging within almost one third (81,000 hectares) of the province total forest (Helbing \& Schult, 2004 in CHIA, 2009) resulted in rapid forest denudation within the area. In the 1950s the forest covered a million hectares on Mindoro. Today only 50,000 hectares remain for the unique and endemic biodiversity (Helle, 2008 in CHIA, 2009).

In 1995, The Crew Development Corporation brought up Mindex, a Norwegian mining company, to the island of Mindoro to apply for a license to test drill for Nickel along the area inhabited by the Alangans, Tadyawans, Bangons and Ruwangs. In 1997, the company was given permission to start the mining exploration. The company plans to start an open-cut mining operation of metal nickel in 2011. This operation will cover 100 square kilometres of forest located within the boundary of Victoria and Sablayan, which serve as source of livelihood to indigenous peoples. This implies that indigenous peoples will lose their lands and forests when mining operation starts.

The forest of Mindoro is characterized by unique biodiversity of the species. A total of 79 and 74 animal and plant (respectively) species can be found in the area. Many of them are endemic and included in the list of international endangered species. One of these is the tamaraw buffalo, a tree frog, and a special species of owl. The mining area is located in the heart of the suggested natural park, the Mangyan Heritage Park and has been designated an area with "extremely high priority" for plants, animals and birdlife. Also, the area is an important watershed for large rivers namely Mag-asawang Tubig, Ibulo, and Aglubang that provide the $70 \%$ of water supply of the province's rice fields and fruit tree plantations (Helle, 2008 in Gariguez 2005).

There is a popular resistance to the mining operation in the province of Mindoro. The Catholic Church, united environmental movements, and local officials are extremely critical about mining. The provincial government of 
Mindoro Oriental initiated in 2002 a 25-year moratorium against any mining operation. The incumbent governor of the province, Attorney Arnan Panaligan together with mayors and congressmen strongly assert the moratorium against the claim of the Ministry of Justice of the Philippines that local moratorium runs counter to the national statute pushed by Gloria Macapagal Arroyo that actively promotes mining operations. The case is now on stalemate and to be decided by the Supreme Court.

Despite the moratorium, the Crew Mining was able to secure from the indigenous peoples a Free, Prior, Informed Consent (FPIC) under the National Commission on Indigenous Peoples (NCIP) Administrative Order Number 1, Series of 2006 and in line to the principles of Indigenous Peoples Rights Act (IPRA). However, intense and deep opposition on the consent has been lobbied by Fr. Edwin A. Gariguez of Mangyan Mission with the widespread support of some public officials and locals. The opposition stemmed out from the accusation of Fr. Gariguez that the process of FPIC was flawed. His statement is based on the following: (1) selective invitation and remoteness of venue; (2) non-observance of inter-agency, LGU and NGO/PO collaboration; (3) non-observance of the prescribed validation of list of elders/leaders; (4) the questionable two million Pesos donation of Crew/Intex resources to NCIP; (5) indirect bribery and external manipulation of indigenous peoples organizations to obtain consent; (6) lack of transparency in information and in presenting the adverse effects of the mining project.

\section{The Concept of Sustainable Development, Ancestral, Domain, and Eco-spirituality among Alangan Mangyans}

This paper poses a basic argument that the concept of sustainable development among Alangan Mangyans is interrelated to the concept of ancestral domain and eco-spirituality. It implies that the analysis of development perspective among Alangan Mangyans entails a holistic investigation of the indigenous notions of ancestral domain and eco-spirituality. This chapter is devoted for discussion on this articulated conceptual interconnectedness.

In the past, lands are considered as communal among Alangan Mangyans. They believe that lands should not be owned privately and be a source of greediness but rather an endowment of the community. The Alangan Mangyans have core belief that lands are owned by their God "Ambuwaw. According to a tribal leader:

"Ang lupa ay hindi dapat angkinin ng sino man kasi pag aari ito ng panginoong si Ambuwaw. The land cannot be owned by anyone because it belongs to our god 'Ambuwaw'."

Ancestral domain is considered as the foundation of consciousness and culture of the Alangan Mangyans. They have an intimate relationship with nature throughout their daily lives. This is where their lives revolve - "kaingin" or swidden farming, hunting wild animals, and other activities as sources of food. The lives of Alangan Mangyans are circumscribe by three major domains of nature namely mountains or forest, rivers, and their "kaingin" or swidden farms. These are the overlaying foundation of their existence and their lives depend on the appropriate utilization of resources. This eco-centric as opposed to anthropocentric perspective is dominant among Alangan Mangyans. An elder asserts:

"Ang lupa ay buhay, kapag sinira ang kalikasan ito ay nangangahulugang kamatayan. Land is life, its destruction will mean death."

Moreover, ancestral lands are not only a source of livelihood for Alangan Mangyans but also considered as spiritual space. The Alangan Mangyans believe "Kapwan Bulod" as protector of mountains and forests, "Alubaba" as protector of rivers, and "Bakwel" as protector of plants and "kaingin" or swidden farms. This eco-spiritual consciousness exhibits the spiritual connectedness of Alangan Mangyans to nature. In this perspective, Alangan Mangyans regard ancestral lands not only in terms of their material resources but also a sacred place - a space for interaction with the Creator and gods.

However, the concept of ancestral domain was transformed from traditional communal to modern private ownership system. The implementation of Certificate of Ancestral Domain Title (CADT) spearheaded by the National Commission on Indigenous Peoples (NCIP) has given the Indigenous Cultural Communities (ICCs) as legal basis to have the sole authority over their lands. This mode of ownership will enable the Alangan Mangyans to claim the royalty as endowment from the mining company. Also, this encouraged the establishment of cultural boundary that is founded on geographical space rather than lineage and heritage. The semi-nomadic nature of the Alangan Mangyans evolved into a community-based settlement based on the territory defined by the CADT. The tribal and familial systems are fragmented as members were dispersed through cultural boundaries and CADT. 
The intrusion of lowlanders "damuong" through mining exploration to the ancestral domains is perceived negatively by Alangan Mangyans. First, it is destructive to their natural resources as they exploit lands, trees and minerals for economic reason. Second, the destruction of natural resources means a threat to the cultural heritage of Alangan Mangyans which is anchored on their ancestral lands and resources. This will fixate the rich cultural beliefs and practices that are based on their environment as articulated by another tribal leader;

"Kung patuloy na sisirain ang kapaligiran, mawalan kami ng pagdadausan ng aming mga ritwal, dasal at kaugalian. Wala na kaming sagradong lugar na paglilibingan ng aming mga patay." If destruction of nature continues, we will be deprived of holy places for our rituals, prayers and practices. There will be no sacred burial sites.

The exploitation of natural resources in the community of Alangan Mangyans is a repercussion of a dominant economic model, the neo-liberalism that intensified through the process of globalization. Corollary to globalization, modernization is highly embraced by modern societies. Modernization theory assumes that societies progress along a path of economic development in which economic forces play the major formative role in shaping social institutions (Frenkel, 1993). Under this economic doctrine, economic development means commodification of resources including in the natural resources. This implies exportation of raw materials from different sectors such as agricultural, forestry, fishery, and mining. The economic principle espoused by the Philippine government increases pressure on our natural resources for economic purposes. According to economists Bela Balassa and Anne Krueger, there is a ladder of development that builds from lower rung in which natural-resource- rich developing countries use their comparative advantage as primary product exporters (Broad, 1995). This type of economic program definitely faces issue on sustainable development.

The key question in the development studies is the nature of development itself-whether it is conceived of primarily as economic growth, better distribution of existing resources, sustainable and ecologically responsible expansion of the economy, poverty alleviation, pursuit of greater levels of political participation and democratization, greater attention of the rights of women and children, liberationist or holistic images of development stressing the rounded encouragement of human potential including its psychological, spiritual and cultural dimensions, or the "conscientization" approach (Clammer, 1996). The concept of sustainable development in the context of Alangan Mangyans is not only an issue of equity or equal distribution of resources. The concept of sustainable development that stresses on equity is considered by Alangan Mangyans as economic and anthropocentric in philosophy. The concept of development is not only economical but rather contextualized by their ownership and utilization of environmental resources for livelihood and preservation of their cultural heritage. Another elder opines that,

"Ang pag unlad ay hindi lang sa pamagitan ng materiyal na bagay...ito ay nangangahulagang pangangalaga ng kapaligiran at pagpapayaman sa kultura." Development is not only a matter of material resources...it means preservation of nature and cultural enrichment.

The economic perspective of sustainable development is confronted by a crucial issue on the utilization of the environmental resources for economic purposes. A central smoldering contradiction was that between globalization and the environment. Globalization and environmental crisis are positively correlated (Bello, 2004). The depletion of natural resources is always a great consideration in development initiatives aside from environmental problem on global warming. The "Theory of Exhaustible Resources" by Harold Hotelling (1931) argued the contemplation for the world's disappearing supplies of minerals, forests, and other exhaustible assets has led to demands for regulation of their exploitation especially in cases where economic laws governing exhaustible resources that yielded a level of resource use according to the individual's self-interest. Policy interventions are needed to induce mine-owners to adopt a schedule of production more in harmony with the public good (Broad, 1995).

\section{The Vestigial Development Perspective of Alangan Mangyans in the Context of Mining Exploration}

The era of globalization generates environmental and socio-cultural changes across different societies. Its complex process involves environmental changes that inevitably cascade to cultural aspect. The influence of etic culture on the cultural heritage of Alangan-Mangyans is now evident. This cultural erosion among ethno-linguistic groups was highlighted by Randolf David (2001) in his statement:

In an important sense, the indigenous people of the world today are the last communities to be sucked into the vortex of globalization. Their surrender to the juggernaut of development signifies the final triumph of economics over culture, of the market over society David (2001). 
The discourse of globalization stratifies different societies. According to Imamanuel Wallerstein, the different parts of the world-system specialize or have different functions. Thus the periphery supplies raw material for the enterprise of the core (Wallace \& Wolf, 1999). This dynamics of globalization tremendously affected the cultural heritage of Alangan Mangyans because of the relentless exploration of minerals in their ancestral domain. The environment and other aspects of the lives of the Alangan Mangyans are now on the process of change. According to an elder,

"Nawawala na ang paraiso, mga halaman, punongkahoy, uway at baging. Nawawala ang dating hanap-buhay."

(There is a deterioration of paradise; depletion of plants, trees, rattan, and vines. The traditional source of livelihood is eventually eroded).

In the same vein, another elder believes that there is an observable deterioration of their environment. He stresses:

"Nawawala na ang pangasuhan at tradisyunal na pagsasaka sa pamamagitan ng kaingin. Nawawala na rin ang pukyutan."

(There is corrosion of hunting grounds and practice of kaingin or swidden farm as traditional farming system. Honey is also becoming scarce).

The cultural diffusion brought by globalization becomes discursive that it has biases to annihilate ethno-linguistic perspective. Herbert Marcuse asserts that:

A totalitarian social order that has succeeded the previous liberal one and that has become one-dimensional because it has eliminated alternative ideas (Wallace \& Wolf, 1999).

This theoretical statement of Marcuse is acknowledged by Alangan Mangyans. They are aware that there is cultural erosion in their society. According to a woman interlocutor,

"Nawawala na ang agpansula, kulturang panggagamot o pagmamaraw, katutubong damit, at pagkakasundo ng mga magulang sa pag-aasawa ng kanilang mga anak."

There is an evident erosion of the culture of agpansula, pagmamaraw or traditional faith healing, traditional clothing, and arranged marriage.

However, despite the consciousness of the Alangan Mangayans on the annihilation of their cultural heritage brought about by acculturation process, there is absence of cultural dissonance among them. On the contrary, Alangan Mangyans are aware that they have to appropriate themselves on the changing environmental, social, economic, and cultural milieu. In other words, they have created an ambivalent culture that facilitates the fluid process of change in their cultural identity. This characteristic is associated to the concept of adaptation. Adaptation in the context of Alangan Mangyans is a function of change; it is an imperative response to changing conditions, as well as a force that allows for further change. It is in this manner that the theoretical convergence between etic and emic cultures is shown in a certain socio-cultural axis.

The theoretical proposition of Bourdieu (in Ritzer, 1996) has been concretely depicted in the process of forming new concepts of sustainable development, ancestral domain, and eco-spirituality among Alangan Mangyans. The process of syncretization of development perspective has been facilitated by the interplay between the internal consciousness of the Alangan Mangyans and the influences coming from the outside, or the interplay between etic and emic development perspective. The interplay of etic and emic development perspective among Alangan Mangyans was contextualized within a mining exploration that characterizes their geographical, environmental, economical, and cultural space.

\section{Amalgamated Religious Beliefs of Alangan Mangyans}

The religious beliefs and practices of the Alangan Mangyans are anchored within the environment. Nature is central to their lives and treated holy and sacred as they believe it is inhabited by gods and spirits of their ancestors. Alangan Mangyans believe "Kapwa Bulod" as protector of mountains and forests, "Alubaba" as protector of rivers, and "Bakwel" as protector of plants and "kaingin" or swidden farms. The spiritual practice of festivity called "Agpamago" during harvesting period is a manifestation of this belief system. This eco-spiritual beliefs hones among them an ecocentric rather than anthropocentric ethos. Succinctly, such cosmology acknowledges the basic notion of Alangan Mangyans on ancestral lands as sacred, holy, life, and culture.

However, the belief system of Alangan Mangyans projects maturity within the womb of a new belief system fastened to the etic influences of major religious groups. The infringement of Pastor Telesforo D. Acbayaan and the Mangyan Mission to the eco-religious beliefs of Alangan Mangyans orchestrated amalgamated religious 
beliefs among them. Alangan Mangyans were circumscribed to adopt and adapt to the religious influences of the formal religious groups and crafted not only amalgamated but also an ambivalent religious identity.

Since 1963, the Catholic Church in Mindoro Oriental has been active in orchestrating outreach programs premised on the context of evangelization and community development. The Mangyan Mission, a catholic-based organization, has long accountable initiatives to empower spiritually, economically and even politically the indigenous peoples of the hinterland. Its empowerment enterprises range from catechism, formal education to advocacy formation among Mangyans.

Pastor Acbayaan is a religious priest who left the formal ministry and immersed to the Alangan Mangyan community since 1986. He is a vibrant agent of evangelization, spending his life with the Alangan Mangyans. Also, he is instrumental in plotting development initiatives in the community being deemed as community leader.

The socio-politico-spiritual activities of Mangyan Mission and Pastor Acbayaan created changes in the dynamics of the religious belief system among Alangan Managyans. The paragon religious belief that considers nature as the locus of gods and spirits has been tainted by the concept of monotheism, believing in one god, Jesus Christ. The introduction of this belief system breaches the basic notion of their belief. An elder states:

"Ngayon naniniwala na kami sa iisang diyos, ang intinuturo ng simbahan. Hindi katulad noong dati na naniniwala lamang kami sa mga espiritu na nakatira sa kalikasan Nagbago na rin ang aming mga kaugalian. Halimbawa, noong una nang hindi pa kami naninniwala sa Kristiyano, ginagawa namin ang kamatayan bilang parusa sa isang taong malaki ang kasalanan."

(Nowadays, we already believe in one god as taught by the church. Unlike before that we believe in spirits embedded in nature. It changes our traditions. Before, when we are not yet believers of Christianism, we practice death as corporal punishment to a person who committed serious crime).

And changes in the religious perspective of the youths among Alangan Mangyans have also been associated to the influences of Christianism. One of the elders comments:

"Ang mga kabataan ngayon ay ayaw ng sumunod sa mga kaugalian ng mga katutubo dahil iba na ang paniniwala nila. Nahihiya na sila sa mga "damuong" dahil naturuan na rin sila ng paniniwalang Kristiyanismo“"

(The youths are not receptive of the indigenous traditions because of the shift in their religious beliefs. The religious teachings of Christianism make them feel uneasy of their traditional beliefs every time they meet the lowlanders.)

At present, the religious belief system of Alangan Mangyans has been into the process of appropriation and re-appropriation because they do not exist in a vacuum. This tendency of religious adaptation makes eco-spiritual dimension of their lives morph into a new form; in this instance and an amalgamated and ambivalent religious practices.

\section{Factors that Facilitate the Transcontextualization of Sustainable Development among Alangan Mangyans}

A combination of different forces has exerted influences on the formation of tranzcontextualized concept of sustainable development, ancestral domain, and eco-spirituality among Alangan Mangyans. The introduction of mining exploration as a manifestation of globalized market enterprise is instrumental in the proliferation of perspectival transformation. The following are the specific factors that facilitated the transcontextualization of the concept of sustainable development, ancestral domain and eco-spirituality among Alangan Mangyans.

1. The mining exploration in the ancestral domains of the Alangan Mangyans and the threat of massive environmental destruction during mining operation. The concept of sustainable development, ancestral domain, and eco-spirituality are anchored on their environment and natural resources, thus any change on it will result to alteration of indigenous perspectives.

2. The abject poverty among Alangan Mangyans that compels them to be receptive of the mining exploration and operation. The promise of annual royalty is very attractive to the Alangan Mangyans. The different forms of dole-out such infrastructure, livestock raising, reforestation, provision of personal transportation (motorcycle) and communication (cellular phones) system to tribal leaders provided by the mining company are perceived positively by the Alangan Mangyans.

3. The peace-loving, non-confrontational culture of the Alangan Mangyans eases the entry of the etic culture. 
4. The increased physical presence of mining laborers from different provinces in the Philippines influences the emic culture of Alangan Mangyans.

5. The mandate of the national government on mining as articulated in the Philippine Mining Act. This government thrust that acknowledges mining as one of the major economic advantages of the Philippines makes the ethno-linguistic groups vulnerable to external pressures.

\section{Improvement of the Stewardship on the Preservation of the Concept of Sustainable Development}

The discursive nature of the etic over emic perspective puts Alangan Mangyans on eventual process of change on their development perspective. This cultural process should be analyzed in order to identify the disadvantageous position of Alangan Mangayans in the formation of a transcontextualized concept of sustainable development, ancestral domain, and eco-spirituality. This nature of analysis will foster the stewardship of Alangan Mangyans on the preservation of their notion of sustainable development. Specifically, the following should be done to empower them in the preservation of their indigenous concept of sustainable development, ancestral domain, and eco-spirituality.

1. Social and cultural interventions should be done in order for the Alangan Mangyans to be conscious about the changes on the environment, economy, social, political and cultural heritage; and their corresponding impacts on the consciousness. This initiative will empower them to be decisive enough on the issues in their society.

2. Participative or consultative planning aimed at developing a culturally sensitive and appropriate interventions to stop or if not, to reverse the immense impact of etic culture among the Alangan Mangyans.

3. Integrate within the education curricula culturally appropriate instructional materials. This will strengthen their appreciation of their indigenous knowledge and cultural heritage.

4. Intensify the anti-mining sentiments within the locality. Conscientizise the locals especially ethno-linguistic groups on the negative effects of mining on different aspects of their lives.

5. Promote active participation of local government units in the promotion of indigenous knowledge and cultural heritage among ethno-linguistic groups.

6. Avoid the relocation of the Alangan Mangyans because it is negatively perceived by them. Relocation according to them will bring changes to their culture and developmental perspective.

\section{Conclusions and Implications}

The formation of transcontextualized concepts of sustainable development, ancestral domain, and eco-spirituality has become apparent among Alangan Mangyans. This phenomenon portrays the dialectical relationship between etic and emic perspective. In the experience of Alangan Mangyans, this convergence was primarily orchestrated by the intrusion of mining company as an agent of globalization on their ancestral domain. However, the process of influence is not unilinear as articulated in the concept of acculturation. This paper proposes a flattened process of cultural influence situating the Alangan Mangyans in equal vantage point with the etic culture.

The findings of this paper can be instrumental in empowering the Alangan Mangyans in the construction and management of their development perspective. Sustainable development among Alangan Mangyans should be anchored on their environment-ancestral domain, which is the locus of their eco-spirituality. As a derivative from this significant consideration in the promotion of sustainable development, several points should be pursued in order to formulate a cultural, environmental and human rights based development framework. The following principles should be considered in any development initiative for Alangan Mangyans:

1. Accommodation of indigenous cultural, social, political, economic and environmental considerations in the direction of the development programs. This principle captures the notion of community-based development initiatives.

2. Empowerment of the Alangan Mangyans over development decisions. There must be devolution of decision-making process to propagate 'bottom-up' development strategies.

3. There is a need to balance the development goals and environmental issues. Development program should not only focus on the protection of the environment and resources but also improve the social capital among Alangan Mangyans.

4. Dialogical development process should be upheld. Collaboration among Alangan Mangyans and development institutions or organizations is very important.

5. There is a need to respect the rights of the Alangan Mangyans. This will include their right to live, ancestral domain, and cultural identities. 
6. The Alangan Mangyans should be recognized for their indigenous ideas, skills, and talents; that they are capable of solving their problems and exploring opportunities for the community without jeopardizing the future generations.

\section{References}

Christiano, Kevin, J., William, H., Santos, Jr., \& Peter Kivisto. (2002). Sociology of Religion. New York: Rowman and Littlefield Publishers, INC.

Cultural Heritage Impact Assessment: Mine Site (Brgy. Villa Cerveza and Brgy. Alcate, Victoria, Mindoro Oriental. 2009.

David, \& Randolf, S. (2001). Reflections on Socilogy and Philippine Society. Philippines: University of the Philippines Press.

Ember, Carol, R., Melvin Ember, \& Peter, N., Peregrine. (2004). Anthropology. New Jersey: Prentice Hall.

Gariguez, Edwin, A. (2008). Articulating Mangyan-Alangans' Indigenous Ecological Spirituality as Paradigm for Sustainable Development and Well-Being. Unpublished Dissertation.

Harold Hotelling. (1931). The Economics of Exhaustible Resources. The Journal of Political Economy, 39(2), 137-175. http://dx.doi.org/10.1086/254195

Macionis, John J. (2003). Sociology. New Jersey: Prentice Hall.

Ritzer, George. (1996). Sociological Theory. New York: McGraw-Hill Companies, INC.

Wallace, Ruth A., \& Alison Wolf. (1999). Contemporary Sociological Theory: Expanding the Classical Tradition. New Jersey: Prentice Hall. 